ORIGINAL RESEARCH PAPER

\title{
DEVELOPMENT OF ELEPHANT FOOT YAM CAKE AND ITS EVALUATION
}

\author{
ANUJ SAKLANI ${ }^{1}$ AND RAVINDER KAUSHIK $* 2$ \\ ${ }^{1}$ Shoolini University, Solan, Himachal Pradesh, India-173229. \\ ${ }^{2}$ University of Petroleum and Energy Studies, Dehradun, India-143226 \\ ${ }^{2}$ ravinder_foodtech2007@rediffmail.com
}

Received on 1 September 2020

Revised on 27 November 2020

\begin{abstract}
Cake is a wheat-based bakery product in which the gluten network development is restricted by fat and sugar. The addition of gluten-free flour is an efficient method to dilute wheat flour for weak gluten. Elephant foot yam is a tuber having multiple health benefits. Therefore, composite flour was prepared by mixing elephant foot yam flour (EFYF) and wheat flour (WF) for cake development. The effect of the addition of EFYF on the quality of the formulated dough and cake was determined. The water and fat absorption capacity varied among the powders obtained from the mixture of EFYF and WF, depending on flours ratios. EFYF was incorporated in WF at different concentrations (10,20, 30 and 40\%) and the dough quality was evaluated. As the EFYF lacks gluten, its addition weakened the gluten network. Cakes prepared from EFYF enriched flours up to $20 \%$ addition had similar texture and sensorial characteristics $(p>0.05)$ in comparison to the control cake. The cake having 20\% EFYF showed the best results in all quality attributes, and is therefore recommended for cake preparation.
\end{abstract}

Keywords: cake, elephant foot yam, textural properties, sensory properties, flour enrichment, composite flours

\section{Introduction}

Amorphophallus paeoniifolius (Dennst.), generally known as Elephant foot yam (EFY), is cultivated at the Eastern boundary of Polynesia, Western Africa, Japan, Philippines, Taiwan, New Guinea, Central Thailand, Southward via Sumatra, Indonesia, Malaysia and several other parts of South Asian Countries, Ceylon and Malaya (Hetterscheid, 1993). The plant is also grown throughout India. Its main producing regions are Bengal, Sikkim, Kerala, Maharashtra, Tamil Nadu, Uttar Pradesh, Punjab, Bihar, Assam and Odisha (Saxena and Brahmam, 1996). The tubers are tremendously rich in nutrients. It is a healthy low-fat food containing a

https://doi.org/10.35219/foodtechnology.2020.2.10 
good amount of protein as well as starch, being also rich in fibre, potassium, calcium $(53 \mathrm{mg} / 100 \mathrm{~g})$, phosphorus $(21 \mathrm{mg} / 100 \mathrm{~g})$ vitamin A $(122 \mathrm{mg} / 100 \mathrm{~g})$, vitamin B6 $(0.2 \mathrm{mg} / 100 \mathrm{~g})$, as well as trace minerals like selenium, zinc and copper (Das et al., 2009). The tubers contain $18.0 \%$ starch, $1-5 \%$ protein and up to $2 \%$ fat. The tubers are quite acrid due to the high content of oxalates (Firdouse et al., 2011).

EFY has been widely used as a natural medicinal product in traditional Indian Ayurveda (De et al., 2010). Amorphophallus paeoniifolius tubers showed gastroprotective, analgesic, antibacterial, antioxidant, anti-tumour, antiinflammatory, antibacterial, antifungal and cytotoxic activities (Khan et al., 2008). Edible plants have always been used for the treatment of many chronic and fatal diseases (Mittal et al., 2020). Amorphophallus paeoniifolius is traditionally used in the treatment of elephantiasis, tumours, inflammations, haemorrhoids, haemorrhages, vomiting, cough, bronchitis, appetizer, asthma, anorexia, dyspepsia, flatulence, colic and constipation (Shilpi et al., 2005). Tubers are mainly consumed after thorough cooking.

Chips and other snacks are also prepared from this starch-rich tuber. Cakes are popular bakery products preferred by most consumers. This is mainly due to its ready-to-eat nature, availability in different varieties and affordable cost. The development of fibre-enriched bakery foods is an important contribution to a broader supply of food products with health beneficial effect (Lohan et al., 2020). Also, cakes have attained a relatively constant place in human diet and their continuous popularity is encouraging the development of newer and more attractive products to put on the market. EFY has wide medicinal applications, therefore, the present study was undertaken to develop and evaluate cakes enriched with elephant foot yam flour. The physicochemical properties of wheat flour mixtures with different ratios of EFYF (10, 20, 30 and 40\%) were analyzed. EFYF and WF cakes were characterized in terms of physicochemical properties and sensory qualities.

\section{Materials and methods}

\section{Sampling}

The EFY was obtained from the local market of Solan, Himachal Pradesh, India. After scraping a fine segment of the peel, the tubers were washed, shredded into 1 $\mathrm{cm}^{3}$ cubes and dried in a mini tray drying oven (Maro Scientific Works Pvt. Ltd., New Delhi, India) for $48 \mathrm{~h}$ at $50{ }^{\circ} \mathrm{C}$. The dried cubes were milled using a rollermill (Chopin Laboratory CD-1 mill, France). To obtain uniform particle size, the flour was sieved through a $60 \mathrm{~mm}$ mesh sieve. The flour was then packed in an airtight plastic container for future use.

All the chemicals used were of analytical grade - sodium hydroxide (98.5\% pure), sulfuric acid (99.5\% pure), petroleum ether (99\% pure), ammonium borate (98.5\% pure). 


\section{Chemical composition of EFY and WF and their proportionate mixture}

The standard methods of AOAC (2005) were used to determine Moisture (AOAC 925.10), fat (AOAC - 2003.05) by Soxhlet extraction, and ash (AOAC - 923.03) by combustion. The protein content (AOAC -960.52$)$ was determined by the Kjeldahl method.

\section{Physicochemical analysis of EFYF and WF}

The EFYF and WF bulk density was determined using the method described by Kaushik et al. (2013). The flour was placed in a $100 \mathrm{ml}$ measuring cylinder and its weight was noted. Bulk density was calculated by dividing weight/volume.

The colour parameters of the flours were measured by means of a Lovibond $\AA$ Tintometer ${ }^{\circledR}$ Colorimeter Model F (The Tintometer Ltd., United Kingdom) based on $\mathrm{L}^{*}, \mathrm{a}^{*}$ and $\mathrm{b}^{*}$ values (Ayadi et al., 2009).

The swelling capacity of the studied flours was determined according to the method proposed by Robertson et al. (2000). In short, $0.2 \mathrm{~g}$ flour was accurately weighed and placed in a graduated test tube; $10 \mathrm{~mL}$ of water containing $0.02 \%$ sodium azide was added, and after thorough mixing, the tubes were allowed to settle for $18 \mathrm{~h}$ at room temperature. Then the bed volume was recorded and the swelling capacity (SC) was calculated as ml per gram of dry sample for $18 \mathrm{~h}$, upon which the final volume attained by the fibre was measured:

$$
\mathrm{SC}(\mathrm{ml} / \mathrm{g})=\frac{\text { Volume occupied by sample }}{\text { Original sample weight }}
$$

The water solubility index (WSI) was determined according to the method devised by Robertson et al. (2000). An amount of $1 \mathrm{~g}$ of flour was added to $10 \mathrm{ml}$ distilled water. The sample was then stirred and the suspension was poured into a centrifuge tube. After centrifugation, the supernatant was dried and the weight of the solids in the supernatant was used to calculate the WSI as a percentage of dry weight of the exudate.

The water-holding capacity and fat-binding capacity were determined using the methods of Kaushik et al. (2015a). The flour sample (500 mg) was dispersed in 10 $\mathrm{ml}$ of water, mixed thoroughly and agitated for $1 \mathrm{~h}$, then centrifuged at $2000 \mathrm{rpm}$ for $30 \mathrm{~min}$. The supernatant was discarded and the sediment was weighed.

To estimate the fat-binding capacity, the flour sample $(500 \mathrm{mg}$ ) was added to $10 \mathrm{ml}$ of refined soybean oil (Fortune brand), mixed thoroughly and agitated for $1 \mathrm{~h}$. Then, the sample was centrifuged at $2000 \mathrm{rpm}$ for $30 \mathrm{~min}$. The supernatant was discarded and the sediment was weighed.

The sodium dodecyl sulfate (SDS) sedimentation was determined as described by Kaushik et al. (2017). The flour $(5 \mathrm{~g})$ was first suspended in $50 \mathrm{ml}$ water and afterwards $50 \mathrm{ml}$ of SDS -Lactic acid reagent (solution containing $0.9 \%$ lactic acid and $2 \%$ SDS) were added. The mixture was allowed to settle for 40 minutes before reading the sedimentation value in $\mathrm{ml}$.

The wet and dry gluten contents were determined by the method described by Kaushik et al. (2015a). The dough was washed and the gluten retained by the 
sieves was collected and weighed for the determination of the wet gluten yield. The dry gluten yield was determined by drying the wet gluten in a freeze dryer for $24 \mathrm{~h}$ and the dry yield was calculated.

\section{Textural analysis of dough and cake}

The texture characteristics of the dough and cake samples were evaluated by the texture profile analysis (TPA) method using a TMS Texture Analyzer (Food Technology Corporation, Sterling, Virginia, USA), equipped with a 1000 (N) load cell, and a $0.05(\mathrm{~N})$ detection range. A dough sample was transferred into a moulded polypropylene tube ( $5 \mathrm{~cm}$ height) that was placed in a fixture to hold it in place under the texture analyzer. An acrylic cylindrical probe was used to compress the sample to $50 \%$ of its original height $(40 \mathrm{~mm})$ at a speed of $10 \mathrm{~mm} / \mathrm{s}$. The equipment was interfaced with a computer, which controlled and analyzed the data, using the software supplied by Texture Technologies Corp. The textural parameters (hardness, cohesiveness, stickiness and adhesion) were calculated from the TPA curves. Hardness represents the peak force of the first compression cycle, stickiness is the distance of the detected height of the product on the second compression divided by the original compression distance, while cohesiveness represents the extent to which the sample could be deformed prior to rupture.

\section{Cake Preparation}

The cake was prepared according to Ceserani et al. (1995) using the following recipe: flour blend $-100 \mathrm{~g}$, fine powder sugar - $24 \mathrm{~g}$, eggs $-80 \mathrm{~g}$, butter $-40 \mathrm{~g}$ and water $-18 \mathrm{ml}$. The sugar was added to the butter and beaten for $3 \mathrm{~min}$. The eggs were beaten and added gradually to the mixture and whipped for 2 min. The EFYF was incorporated in the WF at different concentrations (10,20, 30 and 40\%), and then the butter and sugar whipped cream was added and mixed for $7 \mathrm{~min}$. The cake batter was placed in a baking oven (Electric 2 Deck 4 Tray Oven, TME-2D-4) at a temperature of $170^{\circ} \mathrm{C}$ for $20-25 \mathrm{~min}$. The cakes were cooled and removed from the pan after 30 min. The baked cakes were packaged in aluminium foils and kept on the shelf for sample analysis.

\section{Physical characteristics of cakes}

The volume of cakes was measured using the rape-seed displacement method (Rosell et al., 2001). The weight, length, width and height of the cakes were measured. The textural properties of dough and cakes were measured using a Texture Analyzer. Dough and cake slices $(2.5 \mathrm{~cm}$ thick) were placed on the Texture analyser platform. An acrylic cylindrical probe was used to compress the cake sample up to $50 \%$ of its original height at a speed of $10 \mathrm{~mm} / \mathrm{s}$.

\section{FTIR interpretation}

The microstructural changes were measured by means of a FTIR spectrometer (Rana et al., 2018) (CARY 630 Agilent Technologies, Santa Clara, California, USA). The Microlab Software (Bozeman, Montana, USA) was used to generate data with a resolution of $8 \mathrm{~cm}^{-1}$. The FTIR spectra were recorded in the transmission mode between $4000 \mathrm{~cm}^{-1}$ and $500 \mathrm{~cm}^{-1}$ for the EFYF and WF 
mixtures. The spectra obtained using FTIR were analyzed using a method described by Pavia et al. (2001).

\section{Sensory evaluation}

The sensory evaluation was carried out by students and teachers of the Shoolini University (19 to 37 years old) and was performed at the Food and Nutrition Laboratory. The judges evaluated the following attributes: colour, odour, flavour, taste, texture and overall acceptability. The sensory analysis was conducted using the 10 points hedonic scale, and each judge received the samples in white plastic dishes, numbered with random 3 digits (Kumar et al., 2013). Prior to testing the cake samples were left to cool for $4 \mathrm{~h}$. After cooling the samples were cut and subjected to the sensory assessment panel.

\section{Statistical analysis}

All determinations were performed in triplicates. The data generated was entered and analyzed using Microsoft Office 2010. The means and standard deviation were calculated for the values obtained through the analysis. The analysis of variance (ANOVA) was used to compare the values obtained (Kaushik et al., 2015b). The level of significance was accepted at $p<0.05$.

\section{Results and discussion}

\section{Physical and chemical characterization of EFYF and WF}

The physical properties of the studied flours are summarized in Table 1. Bulk density represents the weight of flour in a given volume, therefore, it is helpful in determining the packaging material required and the area required for storage. The bulk density of EFYF and WF was 0.684 and $0.652 \mathrm{~g} / \mathrm{cm}^{3}$, respectively, and in the different proportionate mixture $(10,20,30$ and $40 \%)$ bulk density increased with the increase in the concentration of EFYF. Although the EFYF bulk density is higher than that of wheat flour, it is not the highest among vegetable flour sources. For instance, Ayadi et al. (2009) determined the bulk density of spiny (Opuntia ficus indica f. amylocea) and spineless cladodes (O. ficus indica f. inermis) powder and found values of 0.703 and $0.647 \mathrm{~g} / \mathrm{cm}^{3}$, respectively. The values of EFYF and WF bulk densities were in between these values. The water solubility index was $27.98 \%$ for EFYF and $31.24 \%$ for WF, and the results revealed that with an increase in the EFYF concentration in the flour mix, the water solubility index decreased. The results showed that the EFY powder was significantly different $(p<0.05)$ in terms of swelling capacity and water solubility index. Flours with high water solubility index have been reported to be good constituents in bakery applications, as they improve solubility characteristics and lead to improved freshness in baked products (Ma et al., 2011). The water holding capacity and fat binding capacity of EFYF were significantly lower $(\mathrm{p}<0.05)$ in comparison to WF, thus it may be said that when increasing the EFYF ratio in the flour mix, the values for the two parameters decreased accordingly. However, in the case of the fat binding capacity, significant differences resulted when the EFYF ratio in the flour mix exceeded $30 \%$, as the contents of $10 \%$ and $20 \%$ of EFYF in the mixture had 
no significant influence ( $p>0.05)$. Water holding capacity represents the ability of a product to associate with water (Singh, 2001). The differences in water absorption are mainly attributed to the greater number of hydroxyl groups that exist in the fibre structure, allowing more water interactions through hydrogen bonding (Rosell et al., 2001). Fat binding capacity is an important feature of polysaccharides. It is partly related to the chemical composition, but more closely linked to the porosity of the fibre structure than to the affinity of the fibre molecule to oil (Biswas et al., 2009).

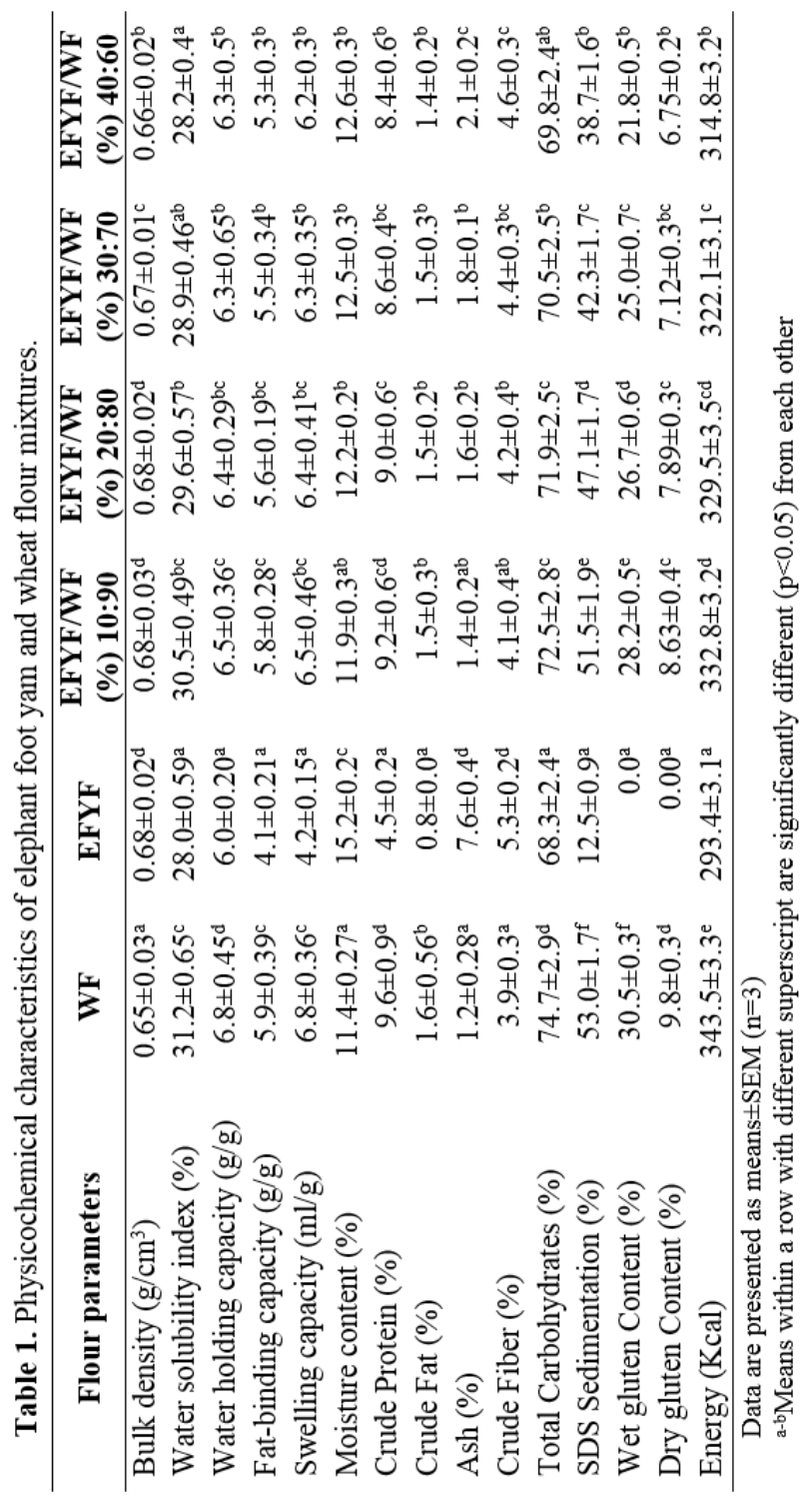


From the data shown in Table 1, it can be observed that by increasing the EFYF ratio above $20 \%$ in the flour mixtures, the moisture content, ash and crude fibre increased significantly $(\mathrm{p}<0.05)$, whereas crude protein and carbohydrates decreased $(p<0.05)$. In the case of the fat content, the EFYF addition had no significant influence $(\mathrm{p}>0.05)$. Similar results were reported for banana cake (Owuno et al., 2009) and bread (Noor et al., 2007).

SDS sedimentation varied in EFYF and WF between 12.47 to $53.02 \%$, respectively, and in a different proportionate mixture of EFYF and WF, the SDS value decreased. The SDS sedimentation volume is a good indicator of wheat flour quality. The present SDS values are in agreement with the values determined by Supekar et al. (2005) for aestivum, durum and dicoccum wheat cultivars. The SDS sedimentation value of wheat flours is based on the fact that gluten absorbs water and swells significantly when treated with lactic acid.

The addition of EFY flour to wheat resulted in a significant decrease of both wet and dry gluten, taking into account that EFY is a gluten free tuber. The wet gluten yield shows the quality of protein and the baking quality of flour. Autran et al. (1997) determined that pentosans and hemicelluloses in flours have a strong effect on gluten yield, and flour processing properties are strongly determined by the way flour milling fractions are mixed. In a response surface study on gluten extraction from low-grade flour and durum flour, it was found that the protein concentration in the protein fraction increased as the water content in the dough increased from 400 to $710 \mathrm{~g} / \mathrm{kg}$ (Dik et al., 2002). Gluten is an important constituent of wheat because it provides strength to dough and texture to baked wheat products. However, the dry gluten yield reported by Singh and Singh (2006) ranged between 5.9 and $10.1 \%$. Supekar et al. (2005) found the dry gluten content to be in the range of 9.4 to $12.7 \%$. A similar dry gluten content was reported by Pharande et al. (1988).

Colour is a significant parameter that includes the physical appearance of the product (Bhandari et al., 2016). Table 2 shows the colour parameters values (L*, $a^{*}$ and $\left.b^{*}\right)$ of EFYF which ranged between $L^{*} 77.51$, $a^{*} 3.89, b^{*} 7.34$ and WF $L^{*}$ $98.12, a^{*} 0.48, b^{*} 11.85$, respectively.

Table 2. Colour characteristics of EFY, WF and different concentrations of flour.

\begin{tabular}{lccc}
\hline Flour & $\mathbf{L}^{*}$ & $\mathbf{a}^{*}$ & $\mathbf{b}^{*}$ \\
\hline WF & $98.1 \pm 2.1^{\mathrm{e}}$ & $0.5 \pm 0.1^{\mathrm{b}}$ & $11.9 \pm 0.5^{\mathrm{d}}$ \\
EFYF & $77.5 \pm 0.8^{\mathrm{a}}$ & $3.89 \pm 0.5^{\mathrm{c}}$ & $7.34 \pm 0.7^{\mathrm{a}}$ \\
EFYF/WF (\%) 10:90 & $96.6 \pm 2.19^{\mathrm{d}}$ & $0.6 \pm 0.1^{\mathrm{ab}}$ & $10.2 \pm 0.5^{\mathrm{c}}$ \\
EFYF/WF (\%) 20:80 & $94.9 \pm 2.11^{\mathrm{c}}$ & $0.6 \pm 0.06^{\mathrm{ab}}$ & $9.6 \pm 0.5^{\mathrm{c}}$ \\
EFYF/WF (\%) 30:70 & $93.1 \pm 2.2^{\mathrm{b}}$ & $0.7 \pm 0.0^{\mathrm{a}}$ & $8.3 \pm 0.4^{\mathrm{b}}$ \\
EFYF/WF (\%) 40:60 & $91.9 \pm 1.6^{\mathrm{b}}$ & $0.7 \pm 0.0^{\mathrm{a}}$ & $8.0 \pm 0.4^{\mathrm{b}}$ \\
\hline
\end{tabular}

The data are presented as means \pm SEM $(n=3)$

${ }^{a-b}$ Means within columns with different superscript letters are significantly different $(p<0.05)$ from each other 
It was observed that as the concentration of the EFYF increased, a slight brown colour was observed in the mixed flour samples. The $L^{*}$ value indicates the lightness, $0-100$ representing dark to light, the $a^{*}$ value gives the degree of the red-green colour, i.e. a higher positive $a^{*}$ value means more red. The $b^{*}$ value indicates the degree of the yellow-blue color, i.e. a higher positive $b^{*}$ value shows more yellow (Ayadi et al., 2009). Upon adding EFYF to WF the most affected parameters were whiteness and yellowness, which decreased significantly $(p<0.05)$ for all the EFY ratios used.

\section{Textural properties of dough and cake}

The textural properties, viz. hardness, cohesiveness, stickiness, and adhesion, were analyzed to determine the effect of EFYF addition to WF on dough quality and the final product obtained - cake. As reported by Carson and Sun (2001), texture analysis is an objective physical examination of baked products and gives direct information on product quality, as opposed to dough rheology tests that provide information on the baking suitability of the flour as raw material. The textural results of dough and cake made of different flour samples are shown in Table 3. The gluten protein network developed in dough is important for the textural properties of baked foods (Sharma et al., 2017).

Table 3. The textural properties of different dough and cake obtained from elephant foot yam flour (EFYF) and wheat flour (WF).

\begin{tabular}{lcccc}
\hline Samples & $\begin{array}{l}\text { Cohesiveness } \\
(\mathbf{m m})\end{array}$ & $\begin{array}{l}\text { Adhesion } \\
(\mathbf{N})\end{array}$ & $\begin{array}{l}\text { Stickiness } \\
(\mathbf{N})\end{array}$ & $\begin{array}{l}\text { Hardness } \\
(\mathbf{N})\end{array}$ \\
\hline \multicolumn{5}{c}{ Textural properties of dough } \\
\hline WF (100\%) & $0.46 \pm 0.033^{\mathrm{b}}$ & $0.20 \pm 0.026^{\mathrm{a}}$ & $0.98 \pm 0.034^{\mathrm{a}}$ & $0.63 \pm 0.029^{\mathrm{a}}$ \\
EFYF (100\%) & $0.41 \pm 0.028^{\mathrm{a}}$ & $0.26 \pm 0.027^{\mathrm{c}}$ & $1.09 \pm 0.031^{\mathrm{b}}$ & $0.98 \pm 0.027^{\mathrm{c}}$ \\
EFYF:WF (\%) 10:90 & $0.44 \pm 0.023^{\mathrm{b}}$ & $0.22 \pm 0.035^{\mathrm{a}}$ & $1.02 \pm 0.038^{\mathrm{ab}}$ & $0.66 \pm 0.036^{\mathrm{a}}$ \\
EFYF:WF (\%) 20:80 & $0.44 \pm 0.031^{\mathrm{a}}$ & $0.24 \pm 0.031^{\mathrm{b}}$ & $1.03 \pm 0.056^{\mathrm{ab}}$ & $0.72 \pm 0.044^{\mathrm{ab}}$ \\
EFYF:WF (\%) 30:70 & $0.43 \pm 0.025^{\mathrm{ab}}$ & $0.25 \pm 0.029^{\mathrm{a}}$ & $1.04 \pm 0.064^{\mathrm{b}}$ & $0.77 \pm 0.042^{\mathrm{b}}$ \\
EFYF:WF (\%) 40:60 & $0.42 \pm 0.029^{\mathrm{ab}}$ & $0.25 \pm 0.025^{\mathrm{b}}$ & $1.05 \pm 0.054^{\mathrm{b}}$ & $0.83 \pm 0.033^{\mathrm{b}}$ \\
\hline \multicolumn{5}{c}{ Textural properties of cake } \\
\hline WF (100\%) $3.21 \pm 0.16^{\mathrm{a}}$ & $1.11 \pm 0.19^{\mathrm{a}}$ & $1.44 \pm 0.34^{\mathrm{a}}$ & $0.98 \pm 0.27^{\mathrm{a}}$ \\
EFYF (100\%) & $3.15 \pm 0.19^{\mathrm{a}}$ & $1.16 \pm 0.21^{\mathrm{b}}$ & $1.55 \pm 0.36^{\mathrm{c}}$ & $1.09 \pm 0.36^{\mathrm{c}}$ \\
EFYF:WF (\%) 10:90 & $3.18 \pm 0.15^{\mathrm{a}}$ & $1.13 \pm 0.24^{\mathrm{ab}}$ & $1.47 \pm 0.41^{\mathrm{b}}$ & $1.01 \pm 0.28^{\mathrm{ab}}$ \\
EFYF:WF (\%) 20:80 & $3.17 \pm 0.24^{\mathrm{a}}$ & $1.14 \pm 0.17^{\mathrm{ab}}$ & $1.49 \pm 0.35^{\mathrm{b}}$ & $1.04 \pm 0.45^{\mathrm{b}}$ \\
EFYF:WF (\%) 30:70 & $3.16 \pm 0.25^{\mathrm{a}}$ & $1.15 \pm 0.11^{\mathrm{b}}$ & $1.53 \pm 0.28^{\mathrm{bc}}$ & $1.06 \pm 0.33^{\mathrm{bc}}$ \\
EFYF:WF (\%) 40:60 & $3.16 \pm 0.31^{\mathrm{a}}$ & $1.15 \pm 0.25^{\mathrm{b}}$ & $1.54 \pm 0.19^{\mathrm{c}}$ & $1.08 \pm 0.27^{\mathrm{bc}}$ \\
\hline The data are presented as means $\pm S E M(\mathrm{n}=3)$ \\
a-b Means within columns with different superscripts are significantly different $(\mathrm{p}<0.05)$ from each \\
other
\end{tabular}

The results showed a great improvement in the textural properties of dough supplemented with EFYF. Except for cohesiveness, all textural parameters 
increased with the EFYF addition. Jeddou et al. (2016) prepared composite flour using potato peel powder and wheat flour for the preparation of cake and reported similar results.

\section{Physical characteristics of cake}

The effect of the EFYF incorporation on the physical properties of the cake is summarized in Table 4. The cake length, width and final weight were not affected by EFYF addition due to the increase of the fibre content; however, height and volume decreased with the addition of EFYF in WF.

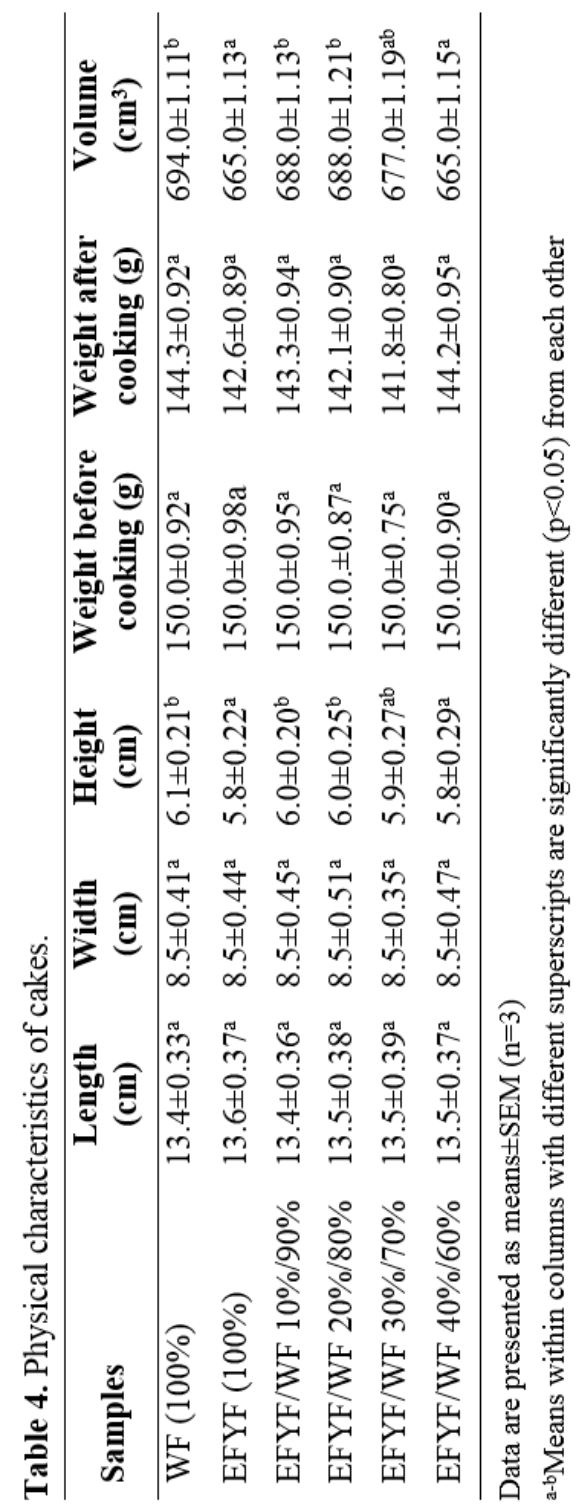


The volume of the control WF cake was $694 \mathrm{~cm}^{3}$ whereas the volume of EFYF was $665 \mathrm{~cm}^{3}$. It was also observed that with the increase in EFYF in the cake, the cake volume decreased. A decrease in cake volume prepared with spiny and spineless cladode powders at a concentration of $10 \%$ as a source of dietary fibre also was reported by (Ayadi et al., 2009).

\section{FTIR analysis}

FTIR is a cheap, fast, reliable, accurate and non-destructive method, used to find the functional groups present in a sample (Schwanninger et al., 2004). The FTIR analysis was carried out to determine the molecular chemistry of flour samples (Figure 1). The FTIR spectra were recorded in transmission mode between $4000 \mathrm{~cm}^{-}$ ${ }^{1}$ and $500 \mathrm{~cm}^{-1}$ for EFYF and WF. The various functional groups present in EFY, WF and their proportionate mixture $(10,20,30$ and $40 \%)$ were Ether $(-\mathrm{C}=\mathrm{C}-\mathrm{O}-\mathrm{C})$, Ester ($\mathrm{C}=\mathrm{O})$, Phenol $(-\mathrm{C}-\mathrm{OH}), 1^{\circ}$ and $2^{\circ}$ Alcohol $(-\mathrm{C}-\mathrm{OH})$ and Alkyl $(-\mathrm{C}-\mathrm{H})$. The FTIR spectrum of the same functional groups in the different samples reflects a similar composition in point of the main constituents. There is no interaction between the functional group of the different samples due to the addition of ingredients. However, it was observed that the absorbance of the samples increased with the addition of increased concentration of EFYF.

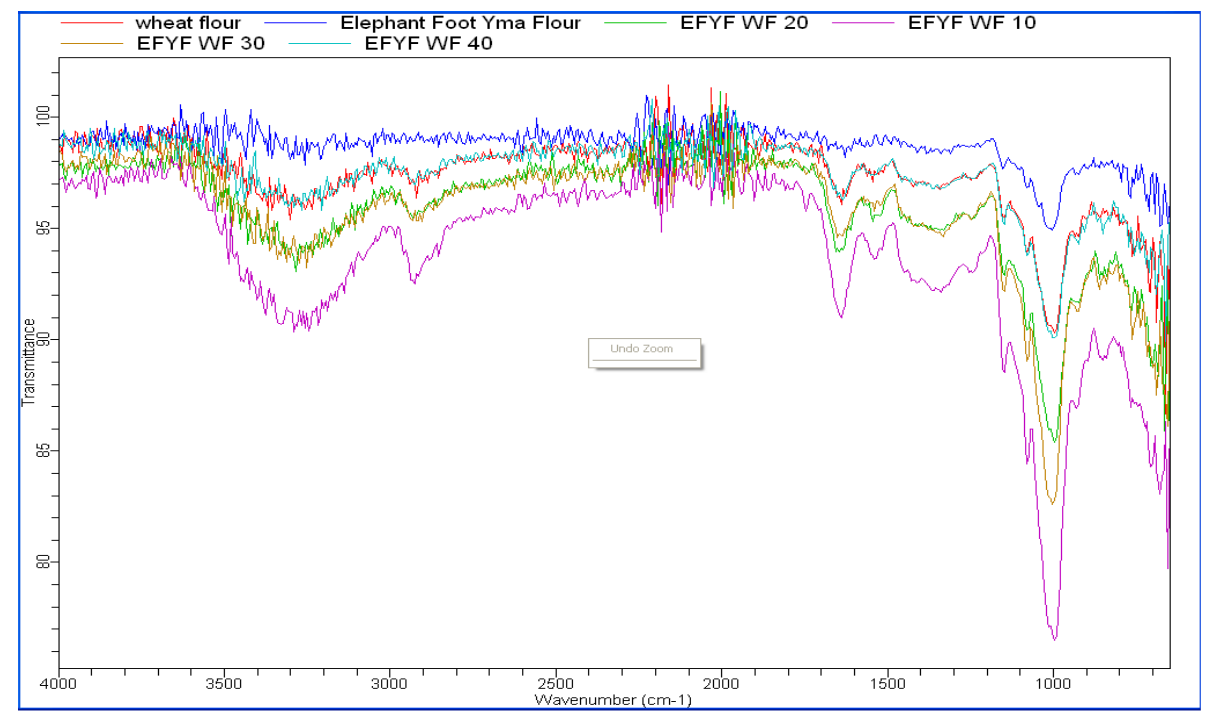

Figure 1. Spectra representation of FTIR analysis of EFYF, WF and different concentration of EFYF and WF.

\section{Sensory Evaluation}

The sensory analysis results are shown in Table 5. The EFYF cake registered lower colour scores in comparison to the other control cake (WF based), and it was observed that with the increase in EFY the colour scores decreased. An insignificant difference $(p>0.05)$ was observed in the textural properties of the 
cake with the addition of EFYF of up to $20 \%$ and the WF based control cake. The taste of the EFYF cake was significantly lower with the increase in EFY concentration in comparison to the control WF based cake. However, the EFY addition of up to $30 \%$ was appreciated as similar to the WF based cake ( $>0.05$ ). In terms of overall acceptability, the appreciation scores were not affected up to $30 \%$ EFY addition, whereas for higher percentages a significant difference was observed. 100\% EFYF was the least appreciated sample, whereas $10 \%$ and $20 \%$ EFYF containing cake showed similar scores in comparison to control for most sensorial characteristics, except colour.

Table 5. Effect of adding different concentration of EFYF on the sensory evaluation of the cake prepared

\begin{tabular}{|c|c|c|c|c|c|}
\hline \multirow[b]{2}{*}{ Cake samples } & \multicolumn{5}{|c|}{ Sensorial characteristics } \\
\hline & Color & Texture & Taste & Odor & $\begin{array}{l}\text { Overall } \\
\text { acceptability }\end{array}$ \\
\hline WF $(100 \%)$ & $8.5 \pm 0.22^{\mathrm{e}}$ & $8.3 \pm 0.24^{c}$ & $8.2 \pm 0.26^{\mathrm{c}}$ & $7.9 \pm 0.27^{b}$ & $8.2 \pm 0.23^{\mathrm{c}}$ \\
\hline EFYF $(100 \%)$ & $7.6 \pm 0.24^{\mathrm{a}}$ & $7.9 \pm 0.28^{\mathrm{a}}$ & $7.5 \pm 0.23^{\mathrm{a}}$ & $7.8 \pm 0.19^{a}$ & $7.7 \pm 0.22^{\mathrm{a}}$ \\
\hline EFYF:WF (\%) 10:90 & $8.4 \pm 0.35^{\mathrm{de}}$ & $8.2 \pm 0.24^{\mathrm{bc}}$ & $8.3 \pm 0.28^{c}$ & $7.9 \pm 0.27^{b}$ & $8.2 \pm 0.21^{\mathrm{c}}$ \\
\hline EFYF:WF (\%) 20:80 & $8.2 \pm 0.23^{\mathrm{d}}$ & $8.2 \pm 0.30^{\mathrm{bc}}$ & $8.3 \pm 0.28^{\mathrm{c}}$ & $7.9 \pm 0.26^{\mathrm{b}}$ & $8.2 \pm 0.25^{\mathrm{c}}$ \\
\hline EFYF:WF (\%) 30:70 & $8.0 \pm 0.33^{\mathrm{c}}$ & $8.1 \pm 0.25^{\mathrm{b}}$ & $8.0 \pm 0.29^{c}$ & $7.8 \pm 0.24^{\mathrm{a}}$ & $8.0 \pm 0.31^{\mathrm{bc}}$ \\
\hline EFYF:WF (\%) 40:60 & $7.8 \pm 0.25^{\mathrm{b}}$ & $8.1 \pm 0.18^{\mathrm{b}}$ & $7.8 \pm 0.27^{b}$ & $7.8 \pm 0.25^{\mathrm{a}}$ & $7.9 \pm 0.22^{\mathrm{b}}$ \\
\hline
\end{tabular}

\section{Conclusions}

An elephant foot yam flour (EFYF) enriched cake was developed with good quality characteristics. Most of the physicochemical properties of EFYF were different from wheat flour (WF). The color of EFYF was slightly brownish. It may be due to the browning reactions during drying. The EFYF enrichmen significantly influenced the textural properties of the cakes prepared with it, since EFY lacks gluten. FTIR showed the interaction between WF and EFYF. The sensory analysis revealed that $20 \%$ of EFYF in the enriched cake had acceptable sensory scores and good quality characteristics. It can be concluded that the enrichment of cake with EFYF is technologically feasible with good sensory acceptability.

\section{Acknowledgments}

This work was conducted in the School of Bioengineering and Food Technology, Shoolini University, Solan, Himachal Pradesh, India. All chemicals, glass ware and instruments were provided by the School of Bioengineering and Food Technology, Shoolini University, Solan, Himachal Pradesh. 


\section{References}

A.O.A.C. 2005. Official methods of analysis. The Association of Official Analytical Chemists (18 ${ }^{\text {th }}$ ed.). 481. North Fredrick Avenue Gaithersburg, Maryland, USA.

Autran, J.C., Hamer, R.J., Plitjer, J.J., Pogna, N.E. 1997. Exploring and improving the industrial uses of wheat. Cereal Foods World, 42, 221-226.

Ayadi, M.A., Abdelmaksoud, W., Ennouri, M., Attia H. 2009. Cladodes from Opuntia ficus indica as a source of dietary fiber: Effect on dough characteristics and cake making. Industrial Crops and Products, 30, 40-47

Bhandari, B.R., Patel, K.C., Chen, X.D. 2016. Spray drying of food materials - process and product characteristics. In: Chen, X.D., Mujumdar, A.S., editors. Drying Technologies in Food Processing. UK: Blackwell Publishing.

Biswas, A.K., Kumar, V., Bhosle, S., Sahoo, J., Chatli, M.K. 2009. Dietary fiber as functional ingredients in meat products and their role in human health. International Journal Livestock Production, 2(4), 45-54.

Carson, L., Sun, X.S. 2001. Creep-recovery of bread and correlation to sensory measurements of textural attributes. Cereal Chemistry, 78, 101-104.

Ceserani, V., Kinkton, R., Foskett, D. 1995. Practical cooking. $8^{\text {th }}$ ed. Holder and Stronghton, London.

Das, S.S., Sen, M., Dey, Y.N., De, S., Ghosh, A.K. 2009. Effects of petroleum ether extract of Amorphophallus paeoniifolius tuber on central nervous system in mice, International Journal of Pharmacy and Life Sciences, 71(6), 651-655.

De, S., Dey, Y.N., Ghosh, A.K. 2010. Phytochemical investigation and chromatographic evaluation of the different extracts of the tuber of Amorphophallus paeoniifolius. International Journal on Pharmaceutical and Biomedical Research, 1(5), 150-157.

Dik, T., Yonderm-Makascioglu, F., Aytac, C.H., Kincal, N.S. 2002. Wet separation of wheat flours into starch and gluten fractions: the combined effects of water to flour ratio-dough maturation time and the effects of flour aging and ascorbic acid addition. Journal of the Science of Food and Agriculture, 82(4), 405-413.

Firdouse. S., Gupta, J., Alam, P., Firdouse, A., Naaz, F., Durrani, M. 2011. Pharmacognostic evaluation of Amorphophallus campanulatus tubers. International Journal of Pharmacy and Life Sciences, 3, 2206-2208.

Hetterscheid, W.L.A. 1993. Sumatran Amorphophallus Adventures: 20 August - 1 September 1993. Aroideana, 17, 61-77.

Jeddou, K.B., Bouaziz, F., Ellouzi, S.Z., Chaari, F., Ellouz, C.S., Ellouz, G.R., Nouri, E.O. 2016. Improvement of texture and sensory properties of cakes by addition of potato peel powder with high level of dietary fiber and protein. Food Chemistry, 217, 668677.

Kaushik, R., Chawla, P., Kumar, N., Kolish, M. 2017. Effect of pre-milling treatments on wheat flour quality. The Annals of the University Dunarea de Jos of Galati - Food Technology, 41(2), 141-152.

Kaushik, R., Sachdeva, B., Arora, S. 2015b. Heat stability and thermal properties of calcium fortified milk. Cyta-Journal of Food, 13(2), 305-311.

Kaushik, R., Sharma, N., Swami, N., Sihag, M., Goyal, A., Chawla, P., Kumar, A., Pawar, A. 2013. Physico-Chemical Properties, Extraction and Characterization of Gluten from 
Different Indian Wheat Cultivars. Research \& Reviews: A Journal of Crop Science and Technology, 2(2), 37-42.

Kaushik, R., Swami, N., Sihag, M., Ray, A. 2015a. Isolation, characterization of wheat gluten and its regeneration properties. Journal of Food Science and Technology, 52(9), 5930-5937.

Khan, A., Rahman, M., Islam, M.S. 2008. Antibacterial, antifungal and cytotoxic activities of amblyone isolated from Amorphophallus campanulatus. Indian Journal of Pharmacology, 40, 41-44.

Kumar, N., Khatkar, B.S., Kaushik, R. 2013. Effect of Reducing Agents on Wheat Gluten and Quality Characteristics of Flour and Cookies. The Annals of the University Dunarea de Jos of Galati - Food Technology, 37(2), 68-81.

Lohan, A., Kaushik, R., Bansal, V., Gandhi, K. 2020. Flax seeds and finger millet enriched functional rusk. International Journal of Food Studies, 9(1), 213-224.

Ma, Z., Boye, J.I., Simpson, B.K., Prasher, S.O., Monpetit, D., Malcolmson, L. 2011. Thermal processing effects on the functional properties and microstructure of lentil, chickpea, and pea flours. Food Research International, 44, 2534-2544.

Mittal, M., Thakur, A., Kaushik, R., Chawla, P. 2020. Physicochemical properties of Ocimum sanctum enriched herbal fruit yoghurt. Journal of Food Processing and Preservation, e14976.

Noor, A., See, E.F., Wan, N.W.A. 2007. Physico-Chemical and Sensory Evaluation of Breads Supplemented with Pumpkin Flour. ASEAN Food Journal, 14, 123-130.

Owuno, F., Eke, J. and Sanni, S.A. 2009. Proximate and sensory properties of banana cakes. Nigeria Food Journal 27, 102-106.

Pavia, D.L., Lampman, G.M., Kriz-jr. G.S. 2001. Introdoction to Spectroscopy: A Guide for Students of Organic Chemistry, $3^{\text {th }}$ Edition, London: Thomson Learning Inc.

Pharande, A.L., Dhotre, V.A., Adsule, R.N. 1988. Quality characteristics of recently released wheat variety. Journal of Maharashtra Agricultural Universities, 13, 234-235.

Rana, B., Kaushik, R., Kaushal, K., Kaushal, A., Gupta S., Upadhay, N., Rani, P., Sharma P. 2018. Application of biosensors for determination of physicochemical properties of zinc fortified milk. Food Bioscience, 21, 117-124.

Robertson, J.A., Monredon, F.D., Dysseler, P., Guillon, F., Amadò, R., Thibault, J.F. 2000. Hydration properties of dietary fiber and resistant starch: a European Collaborative Study. Food Science and Technology, 33, 72-79.

Rosell, C.M., Rojas, J.A., Benedito de Barber, C. 2001. Influence of hydrocolloids on dough rheology and bread quality. Food Hydrocolloids, 15, 75-81.

Saxena, H. O., Brahmam, M. 1996. The Flora of Orissa. IV: 2037-2039

Schwanninger, M., Rodrigues, J.C., Pereira, H., Hinterstoisser, B. 2004. Effects of shorttime vibratory ball milling on the shape of FT-IR spectra of wood and cellulose. Vibrational Spectroscopy, 36(1), 23-40.

Sharma, N., Khatkar, B., Kaushik, R., Sharma P., Sharma R. 2017. Isolation and development of wheat based gluten edible film and its physico-chemical properties. International Food Research Journal, 24(1), 94-101.

Shilpi, J.A., Ray, P.K., Sarder, M.M., Uddin, S.J. 2005. Analgesic activity of Amorphophallus paeoniifolius tuber. Fitoterpia; 76, 367- 369. 
Singh, B., Singh, N. 2006. Physico-chemical, water and oil absorption and thermal properties of gluten isolated from different Indian wheat cultivars. Journal of the Science Technology, 43(3), 251-255.

Singh, U. 2001. Functional properties of grain legume flours. Journal of Food Science and Technology, 38(3), 191-199.

Supekar, D.T., Patil, S.R., Munjal, S.V. 2005. Comparative study of some important aestivum, durum and dicoccum wheat cultivars for grain, flour quality and suitability for chapati making characteristics. Journal of the Science Technology, 42(6), 488-492. 